\title{
Targeting FoxM1 transcription factor in T-cell acute lymphoblastic leukemia cell line
}

\author{
Özlem Tüfekçii ${ }^{a}$, Melis Kartal Yandım ${ }^{\mathrm{b}}$, Hale Ören ${ }^{\mathrm{a}, *}$, Gülersu İrken ${ }^{\mathrm{a}}$, Yusuf Baran ${ }^{\mathrm{b}}$ \\ a Dokuz Eylül University, Faculty of Medicine, Department of Pediatric Hematology, Balçova, Izmir, Turkey \\ ${ }^{\mathrm{b}}$ Izmir Institute of Technology, Faculty of Science, Department of Molecular Biology and Genetics, Urla, Izmir, Turkey
}

\section{A R T I C L E I N F O}

\section{Article history:}

Received 19 August 2014

Received in revised form

25 November 2014

Accepted 9 December 2014

Available online 17 December 2014

\section{Keywords:}

Dexamethasone

FoxM1

Jurkat cells

Siomycin A

T-cell acute lymphoblastic leukemia

\begin{abstract}
A B S T R A C T
The Forkhead box protein M1 (FoxM1) is an important transcription factor having significant roles in various cellular events. FoxM1 overexpression has been reported to be related with many types of cancer. However, it is not known whether it contributes to oncogenesis of acute lymphoblastic leukemia. Siomycin A, a thiazol antibiotic, is known to inhibit FoxM1 transcriptional activity. In this study, we aimed to determine gene expression levels of FoxM1 in Jurkat cells (T-cell acute lymphoblastic leukemia cell line) and therapeutic potential of targeting FoxM1 by siomycin A alone and in combination with dexamethasone which improves the survival of children with T-cell acute lymphoblastic leukemia (ALL). We also examined the molecular mechanisms of siomycin A and dexamethasone-induced cell death in Jurkat cells. We demonstrated that FoxM1 mRNA is highly expressed in Jurkat cells. Dexamethasone and siomycin A caused a significant reduction in gene expression levels of FoxM1 in Jurkat cells. Targeting FoxM1 by siomycin A and dexamethasone caused a significant decrease in T-ALL cell line proliferation through induction of G1 cell cycle arrest. All these findings suggest a possible role of FoxM1 in T-cell ALL pathogenesis and represent FoxM1 as an attractive target for T-cell ALL therapy.
\end{abstract}

(c) 2014 Elsevier Ltd. All rights reserved.

\section{Introduction}

Acute lymphoblastic leukemia (ALL) is the most common malignancy among children [1]. The cure rates for childhood ALL have increased significantly in recent decades due to better definition of risk groups to modulate the intensity of treatment, introduction of new antineoplastic drugs and enhanced supportive care with better control of infections [2-4]. Despite markedly improved survival rates, the prognosis remains poor for some group of patients [5]. The cure rate for T-cell ALL, comprising about $15 \%$ of pediatric ALL, is lower compared to B-cell ALL, but recently the outcome for patients with T-cell ALL also improved significantly with high dose dexamethasone during remission induction [6,7].

While there have been significant developments in defining the molecular abnormalities of ALL, it is not clear how these abnormalities cooperate to cause leukemia and/or drug resistance. Recent studies on pathogenesis and prognosis of leukemia have led to development of new-targeted therapies. The newly developed

\footnotetext{
* Corresponding author at: Dokuz Eylül University, Faculty of Medicine, Department of Pediatric Hematology, 35340 Balçova, Izmir, Turkey. Tel.: +90 532 6669050; fax: +902324126005.

E-mail address: hale.oren@deu.edu.tr (H. Ören).
}

targeted therapies, if proven effective, may eventually allow us to minimize conventional antineoplastics and the associated toxicities, while maximizing survival and minimizing relapse [5]. The Forkhead box protein M1 (FoxM1) belongs to the Forkhead superfamily of transcription factors which all share an evolutionary conserved 'winged helix' DNA-binding domain [8,9]. The expression of FoxM1 is restricted to cells that are proliferating and its expression is negatively regulated in terminally differentiated cells. However, its expression is induced when cells re-enter the cell cycle $[8,10,11]$. It has been accepted that FoxM1 is a key cell cycle regulator, affecting the transcriptional activity of cell-cycle genes essential for both transition from $G_{1}$ to $S$ phase and progression to mitosis, including cyclin $B$, polo-like kinase-1 (Plk-1), Cdc25B phosphatase, Aurora kinase, Cdc25A, cyclin D1, and p21 Cip1 p27 Kip1 [8]. Furthermore, depletion of FoxM1 has been shown to cause mitotic spindle defects, cell cycle arrest, chromosome misaggregation and mitotic catastrophe [12,13]. Recent reports have also demonstrated that FoxM1 plays important roles in cellular developmental pathways including the maintenance of homeostasis between cell proliferation and apoptosis and as a result, alterations in FoxM1 signaling has been reported to be associated with carcinogenesis and tumor aggressiveness [8,9,14]. Recently emerging evidence reveals that FoxM1 signaling network is disturbed and upregulated in many solid human tumors like lung 
cancer, glioblastomas, prostate cancer, basal cell carcinomas and pancreas cancer [15-19]. These results give rise to some questions about the role of FoxM1 in pathogenesis of leukemia. FoxM1 mRNA has been reported to be expressed in single or double positive $T$ lymphocytes in thymus during T-cell development but it is not expressed in peripheral blood lymphocytes. However, it has also been shown that FoxM1 is induced upon stimulation with mitogens in vitro, resulting in lymphocyte division [11]. There has been only one study reported in the literature investigating the role of FoXM1 in leukomogenesis [20]. That study has shown that FoxM1 is highly expressed in acute myeloid leukemia (AML) cells and increased expression of FoxM1 leads to proliferation of leukemia cells. In this context, targeting FoxM1 may represent a promising strategy for the development of novel and selective anticancer therapies.

Siomycin A, a thiazole antibiotic, is a Gram positive bacteriaspecific sulfur containing antibiotic. Genetic and biochemical studies showed that thiazole antibiotics (thiostrepton, siomycin, thiopeptin, sporangiomycin, and noshipeptide) block the translocation step of translation by binding to the 23S rRNA on the 50S ribosomal subunit, but they do not exert any inhibitory effect on eukaryotic protein synthesis. Siomycin A was identified as a strong proapoptotic compound in epithelial cells and also as a potential anticancer drug that causes apoptosis and induces lysosomal membrane permeabilisation [21]. Siomycin A has been shown to downregulate the transcriptional activity and also the protein and mRNA levels of FoxM1 in human cancer cell lines [22-24].

In this study, we aimed to determine gene expression levels of FoxM1 in Jurkat cells (T-ALL cell line) and therapeutic potential of targeting FoxM1 by siomycin A alone and in combination with dexamethasone which improves the survival of children with T-cell ALL. We also examined the molecular mechanisms of siomycin A and dexamethasone-induced cell death in Jurkat cells.

\section{Methods}

\subsection{Cell line and chemicals}

Human Jurkat T-cell leukemia cells were obtained from German Collection of Microorganisms and Cell Cultures (Germany). Siomycin A was obtained from Sigma-Aldrich (USA) and stock solution $(0.3 \mathrm{mM})$ was dissolved in dimethylsulfoxide (DMSO). Dexamethasone was obtained from Deva Holding (Istanbul, Turkey) and stock solution ( $1 \mathrm{mM}$ ) was dissolved in DMSO.

\subsection{Culture conditions}

Jurkat human T-cell leukemia cells were maintained in RPMI1640 growth medium containing $10 \%$ fetal bovine serum and $1 \%$ penicillin-streptomycin at $37^{\circ} \mathrm{C}$ in $5 \% \mathrm{CO}_{2}$.

\subsection{Peripheral blood mononuclear cell (PBMC) isolation from healthy donors}

Mononuclear cells from blood samples of healthy donors were isolated by lysis buffer including $155 \mathrm{mM} \mathrm{NH}_{4} \mathrm{Cl}$ and $10 \mathrm{mM} \mathrm{KHCO}_{3} .10 \mathrm{~mL}$ lysis buffer was added onto blood sample in a sterile falcon tube, and shaked by orbital shaker for $10 \mathrm{~min}$. Then, blood sample in the falcon tube was centrifuged at $8000 \times g$ for $5 \mathrm{~min}$, and supernatant was removed. The pellet was homogenized with $2 \mathrm{~mL}$ lysis buffer, and then centrifuged again at $8000 \times g$ for $5 \mathrm{~min}$, and then this step was repeated. Afterwards, the pellet was washed by $2 \mathrm{~mL}$ PBS, and centrifuged at $8000 \times \mathrm{g}$ for $5 \mathrm{~min}$. After the centrifugation, supernatant was removed, and the pellet was homogenized, and isolated peripheral blood mononuclear cells were counted by hemocytometer.

\subsection{Measurement of FoxM1 expression level by reverse transcriptase polymerase chain reaction}

FOXM1 expression levels of Jurkat cells and PBMCs were assessed by RT-PCR. Jurkat cells were treated with increasing concentrations of $\operatorname{siomycin}(0.01-0.05 \mu \mathrm{M})$ and dexamethasone $(0.1-10 \mu \mathrm{M})$ for $72 \mathrm{~h}$. After the incubation period, RNA samples were isolated, and then cDNA synthesis was executed. Then, PCR was carried out at $94^{\circ} \mathrm{C}$ for $5 \mathrm{~min}$ (initial denaturation), $94^{\circ} \mathrm{C}$ for $1 \mathrm{~min}, 57^{\circ} \mathrm{C}$ for $1 \mathrm{~min}, 72^{\circ} \mathrm{C}$ for $1 \mathrm{~min}$ (final extension), and $72^{\circ} \mathrm{C}$ for $5 \mathrm{~min}$. This reaction was carried out for 35 cycles.

\subsection{Measurement of cell growth by MTT assay}

Cytotoxic effects and $\mathrm{IC}_{50}$ values (drug concentrations inhibiting cell growth by $50 \%$ ) of siomycin A and dexamethasone were determined by MTT cell proliferation assay. In short, $1 \times 10^{4}$ cells/well were seeded into 96 -well plates containing $100 \mu \mathrm{l}$ of the growth medium in the absence or presence of increasing concentrations of siomycin A and dexamethasone, and then incubated at $37{ }^{\circ} \mathrm{C}$ in $5 \% \mathrm{CO}_{2}$ for $72 \mathrm{~h}$. After incubation period, cells were treated with $20 \mu \mathrm{l}$ of MTT for $3 \mathrm{~h}$. Then, plates were centrifuged for $10 \mathrm{~min}$ at $1800 \mathrm{rpm}$. After centrifugation, supernatants were removed from the plates and then the MTT crystals were homogenized by adding $100 \mu \mathrm{l}$ of DMSO into each well. In order to homogenize the pellets more efficiently, the plates were shaken for $5 \mathrm{~min}$ by shaker. Afterwards, the plates were read under $570 \mathrm{~nm}$ wavelengths by ELISA reader (Thermo Electron Corporation Multiskan Spectrum, Finland). Finally, $\mathrm{IC}_{50}$ values of siomycin A and dexamethasone were calculated according to the cell proliferation plots.

In order to determine the possible synergistic effects of dexamethasone in combination with siomycin $\mathrm{A}, \mathrm{IC}_{50}$ value of siomycin $\mathrm{A}$ and increasing concentrations of dexamethasone $(0.1-50 \mu \mathrm{M})$ were applied onto the cells, and then same procedure was carried out.

\subsection{Analysis of apoptotic cells by FITC Annexin-V staining}

We determined the translocation of phosphatidylserine from the inner membrane to the outer cell membrane. Initially, $5 \times 10^{5}$ cells were treated with increasing concentrations of dexamethasone $(1-50 \mu \mathrm{M})$ alone or in combinations with the $\mathrm{IC}_{50}$ value of siomycin $\mathrm{A}(0.46 \mu \mathrm{M})$ for $72 \mathrm{~h}$. After the incubation period, the cells were washed twice with cold phosphate buffered saline (PBS) and then resuspended with $1 \mathrm{~mL} 1 \times$ binding buffer. Then, $100 \mu \mathrm{l}$ of this solution was added into glass tubes. $5 \mu \mathrm{l}$ of FITC Annexin-V and $10 \mu \mathrm{l}$ of PI were added onto the cell solutions. These samples were vortexed gently and then incubated for $15 \mathrm{~min}$ at RT in the dark. Afterwards, $400 \mu \mathrm{l}$ of $1 \times$ binding buffer was added to each tube, and then they were analyzed by flow cytometry (BD Facscanto Flowcytometry, Belgium) within $1 \mathrm{~h}$.

\subsection{Cell cycle analysis}

This technique is based on the determination of amounts of dsDNA by using propidium iodide, a DNA-binding dye, via flow cytometry. When the data acquired from the flow cytometry are analyzed, cell cycle phases and the amounts of fragmented DNA of the cells can be determined. Briefly, $5 \times 10^{5}$ cells/well were treated with increasing concentrations of dexamethasone $(1-10 \mu \mathrm{M})$ alone or in combination with $0.46 \mu \mathrm{M}$ siomycin A for $72 \mathrm{~h}$. After the incubation period, the cells were collected by centrifugation at $260 \times g$ for $10 \mathrm{~min}$. Supernatants were removed, pellets were homogenized with $1 \mathrm{~mL}$ of cold PBS, and the samples were put on ice. Afterwards, while the cells were slightly vortexed, $4 \mathrm{~mL}$ of cold ethanol was added onto the cells, and then again put on ice. Cells fixed by this method were incubated overnight at $-20^{\circ} \mathrm{C}$ for the analysis. Next day, the cells were centrifuged at $260 \times g$ for $10 \mathrm{~min}$, and supernatants were completely removed from the pellets. Pellets were washed with $1 \mathrm{~mL}$ of cold PBS, and centrifuged again at $260 \times \mathrm{g}$ for $10 \mathrm{~min}$. Afterwards, cell pellets were homogenized with $1 \mathrm{~mL}$ of PBS containing $0.1 \%$ Triton $\mathrm{X}-100$, and $100 \mu \mathrm{l}$ of RNase $\mathrm{A}(200 \mu \mathrm{g} / \mathrm{mL})$ was added onto the cells. After incubation at $37^{\circ} \mathrm{C}$ for $30 \mathrm{~min}, 100 \mu \mathrm{l}$ of PI $(1 \mathrm{mg} / \mathrm{mL})$ was added onto the cells. These cells were incubated at room temperature for $15 \mathrm{~min}$, and then analyzed via flow cytometry.

\subsection{Total RNA isolation and profiling the gene expression patterns by $R T^{2}$ Profiler PCR array}

Total RNAs from Jurkat cells, exposed to $10 \mu \mathrm{M}$ dexamethasone and $0.46 \mu \mathrm{M}$ siomycin A alone or in combination, were isolated by NucleoSpin RNA isolation kit (Macherey-Nagel GmbH, Germany) as described by the manufacturer. $1 \mu \mathrm{g}$ of total RNA was treated with Genomic DNA Elimination Mixture provided by RT $^{2}$ First Strand Kit (SABiosciences Corporation, USA). After an incubation period of $5 \mathrm{~min}$ at $42^{\circ} \mathrm{C}$, samples were chilled on ice for $1 \mathrm{~min}$. In the course of the incubation period mentioned previously, RT cocktail was prepared as described by the manufacturer. Then, $10 \mu \mathrm{l}$ of RT cocktail was added to each of $10 \mu \mathrm{l}$ Genomic DNA Elimination Mixture. Samples were incubated at $42^{\circ} \mathrm{C}$ for $15 \mathrm{~min}$ and then the reaction was stopped by heating at $95^{\circ} \mathrm{C}$ for $5 \mathrm{~min}$, and by this way, cDNAs were acquired. $91 \mu \mathrm{l}$ of distilled water was added to each $20 \mu \mathrm{l}$ of cDNA synthesis reaction. Afterwards, expression profiles of the genes which play important roles in cell cycle, DNA damage and repair, angiogenesis, apoptosis, cell senescence, epithelial-to-mesenchymal transition, hypoxia, metabolism, and also telomeres and telomerase were analyzed by $\mathrm{RT}^{2}$ Profiler PCR Array, a reliable and sensitive gene expression profiling technique. After adding $25 \mu \mathrm{l}$ of experimental cocktail into each well of the PCR Array plate preloaded with real-time PCR primers of pathway-focused genes, reaction was executed in real-time thermal cycler (Roche LightCycler 480, Germany) [25].

The genes belong to different gene families that have important roles in many cellular processes used in this study are as the following: 

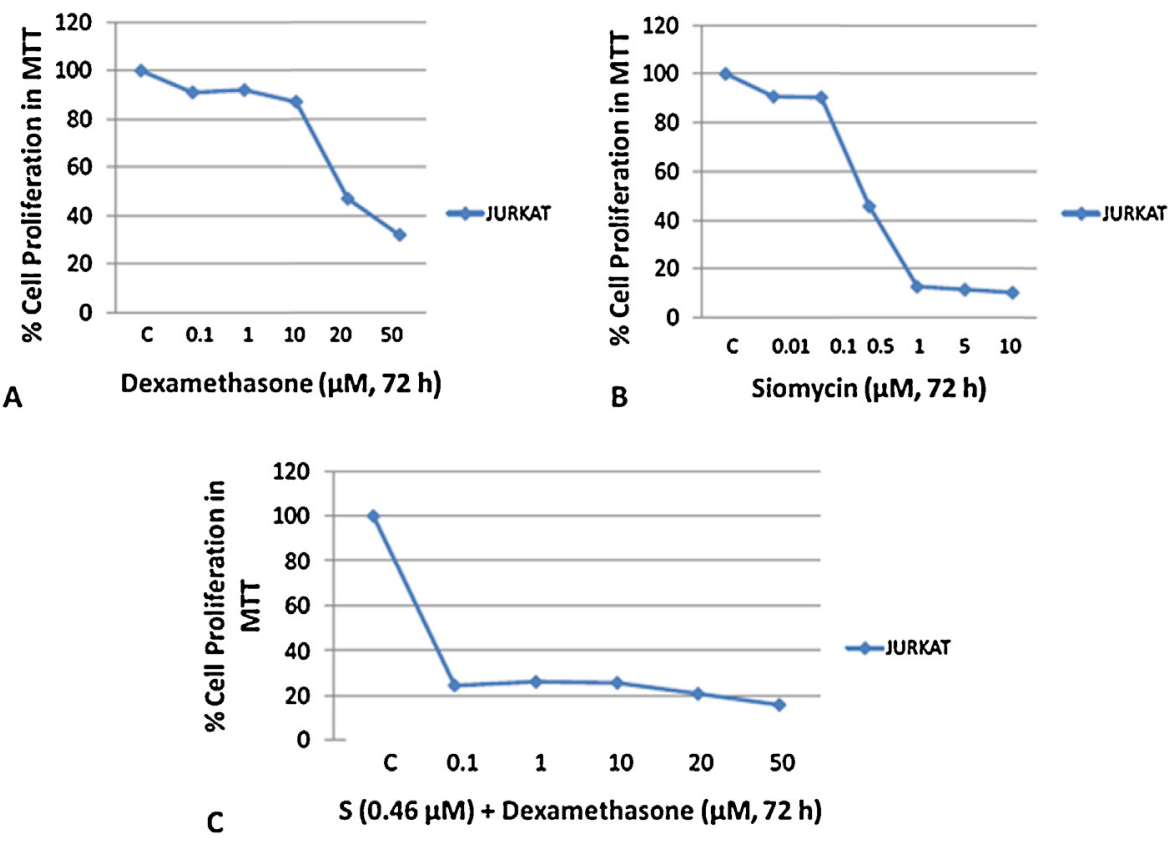

Fig. 1. Cytotoxic effects of dexamethasone (A) siomycin (B) and combination of siomycin with dexamethasone (C) on Jurkat cells.

Apoptosis: APAF1, BCL2L11, BIRC3 (c-IAP1), CASP2, CASP7, CASP9, CFLAR (CASPER), FASLG (TNFSF6), NOL3, XIAP.

Cell cycle: AURKA, CCND2, CCND3, CDC20, E2F4, MCM2, MKI67, SKP2, STMN1, WEE1.

Cell senescence: BMI1 (PCGF4), ETS2, IGFBP3, IGFBP5, IGFBP7, MAP2K1, MAP2K3, MAPK14, SERPINB2 (PAI-2), SOD1, TBX2.

DNA damage and repair: DDB2, DDIT3 (GADD153/CHOP), ERCC3 (XPB), ERCC5, GADD45G, LIG4, POLB, PPP1R15A (GADD34).

Epithelial-to-mesenchymal transition: CDH2 (N-cadherin), DSP, FOXC2, GSC, KRT14, OCLN, SNAI1, SNAI2, SNAI3, SOX10.

Hypoxia: ADM, ARNT, CA9, EPO, HMOX1, LDHA, SLC2A1.

Metabolism: ACLY, ACSL4, ATP5A1, COX5A, CPT2, G6PD, GPD2, LPL, PFKL, UQCRFS1.

Telomeres and telomerase: DKC1, PINX1, TEP1, TERF1, TERF2IP, TINF2, TNKS (TIN1), TNKS2.

\section{Results}

We showed that FoxM1 mRNA is highly expressed in Jurkat cells and inhibition of this transcription factor resulted in a profound decrease in leukemic cell proliferation.

\subsection{Antiproliferative effects of dexamethasone and siomycin $A$} alone or in combination on human Jurkat T-cell leukemia cells

As shown in Fig. 1A, dexamethasone decreased proliferation of Jurkat cells in a dose dependent manner. According to cell proliferation plot, $\mathrm{IC}_{50}$ value of dexamethasone was found to be $19 \mu \mathrm{M}$ (Fig. 1A). As shown in Fig. 1B, siomycin A decreased proliferation of Jurkat cells. $\mathrm{IC}_{50}$ value of siomycin $\mathrm{A}$ was found to be $0.46 \mu \mathrm{M}$ (Fig. 1B). Combination of dexamethasone with siomycin A decreased cell proliferation of Jurkat cells synergistically as compared to any agent alone (Fig. 1C).

\subsection{Effects of dexamethasone and siomycin A alone or in their combinations on apoptotic cell population}

There were both increases and decreases in percentages of apoptotic cell populations in response to dexamethasone, as compared to untreated control group (Fig. 2A and B). However, increases in apoptotic cell population were observed in the cells treated with
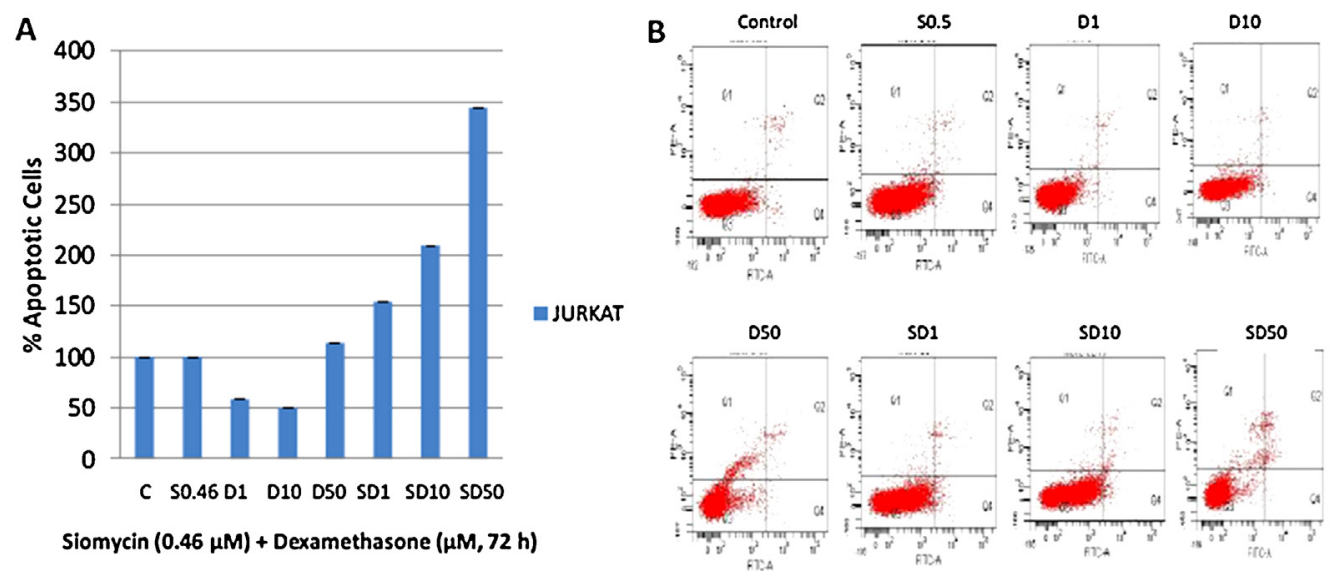

Fig. 2. Apoptotic effects of siomycin and dexamethasone alone or their combinations on Jurkat cells (A) and flow cytometry results (B). 


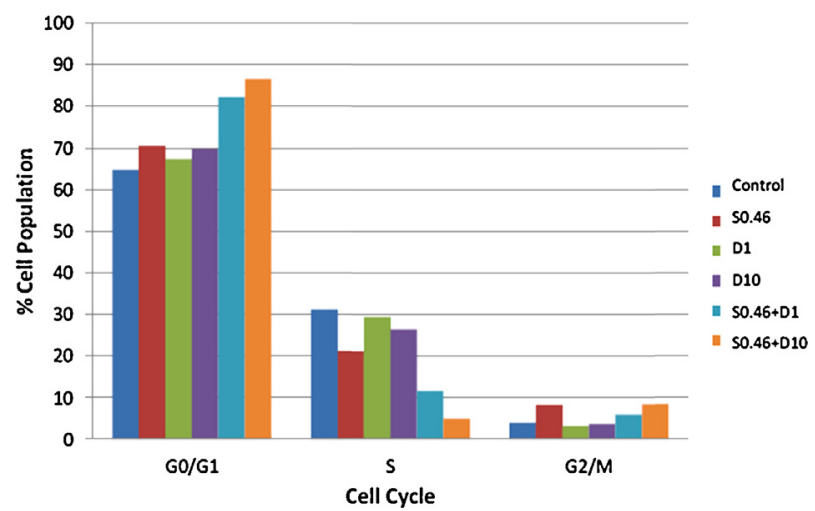

Fig. 3. Effects of siomycin and dexamethasone alone or their combinations on cell cycle progression of Jurkat cells.

combinations of dexamethasone and $0.46 \mu \mathrm{M}$ siomycin A. There were 55,109 , and $245 \%$ increases in response to 1,10 , and $50 \mu \mathrm{M}$ dexamethasone in combination with $0.46 \mu \mathrm{M}$ siomycin A (Fig. 2A).

\subsection{Effects of dexamethasone and siomycin A alone or in combination on cell cycle progression}

Cell cycle analyses revealed that, 1 and $10 \mu \mathrm{M}$ dexamethasone application resulted in cell cycle arrest at G0/G1 phase while siomycin alone arrested cell cycle progression both in G0/G1 and G2/M phases. Treatment with combinations of 1 and $10 \mu \mathrm{M}$ dexamethasone in combination with $0.46 \mu \mathrm{M}$ siomycin A mostly accumulated at G0/G1 phase significantly. The results demonstrated that dexamethasone and siomycin A synergistically inhibited cell cycle progression, and they arrest cell cycle at G0/G1 phase transition (Fig. 3).

\subsection{The expression of FoxM1 mRNA in healthy donor and Jurkat human T-cell leukemia cells treated with dexamethasone and $\operatorname{siomycin} A$}

Expression levels of FoxM1 in Jurkat cells treated with increasing concentrations of dexamethasone and siomycin A were found to be decreased in a dose-dependent manner as normalized to beta actin, internal positive control (Fig. 4). The most significant decreases were observed in $0.5 \mu \mathrm{M}$ of siomycin A and $10 \mu \mathrm{M}$ dexamethasone (Fig. 4). Furthermore, expression levels of FOXM1 in Jurkat cells were significantly higher as compared to PBMC from healthy donors (Fig. 5).

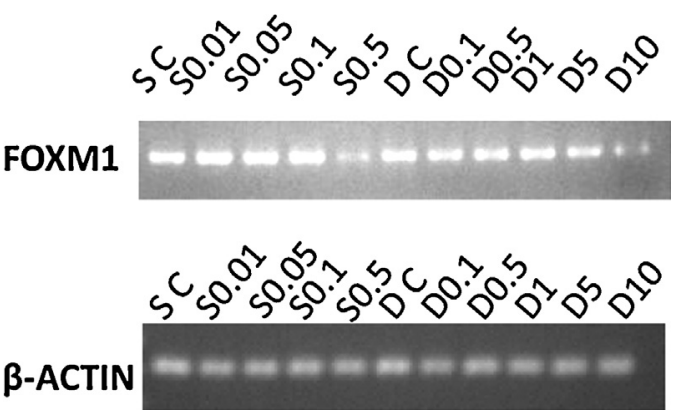

Fig. 4. Expression levels of FoxM1 gene in Jurkat cells treated with siomycin and dexamethasone.

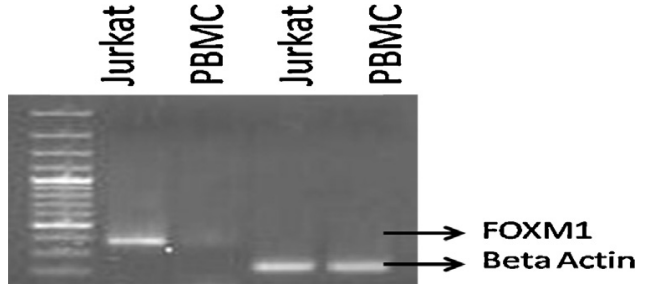

Fig. 5. Expression levels of FoxM1 gene in PBMCs and Jurkat cells.

3.5. Changes in expression profiles of 84 genes in Jurkat human T-cell leukemia cells exposed to dexamethasone and siomycin A alone or in combination of both of the agents

As shown in Table 1, the results showed that there were significant increases (more than 3-fold) and decreases (more than 1.5-fold) in expression levels of several genes among 84 genes in response to $0.46 \mu \mathrm{M}$ siomycin $\mathrm{A}, 10 \mu \mathrm{M}$ dexamethasone, and combination of these agents. The genetic expressions changed significantly were found to be related with tumor suppressing, apoptosis, cell cycle regulation, adhesion, DNA damage and repair, and cell metabolism. As compared with untreated control group, expression levels of CCND3 gene (related with cell cycle), MAP2K3 and IGFBP7 (related with cell senescence) increased in response to combination therapy as compared to any agent alone. Moreover, expression levels of ETS2 proto-oncogene regulating telomerase activity, CDC20 gene involved in cell cycle regulation, MCM2 gene which is important in the formation of pre-replication complex and replication fork, and also MK167 gene which is involved in cell proliferation were found to be decreased in response to combinational treatment as compared to any agent alone.

\section{Discussion}

Recent studies including genomewide expression profiles have demonstrated that FoxM1 signaling network is disturbed and highly expressed in many human malignancies [15-20]. The present study also showed that FoxM1 mRNA is highly expressed in T-cell ALL line and inhibition of this transcription factor resulted in a profound decrease in leukemic cell proliferation. The increased expression levels of FoxM1 in tumor cells might be thought as a result of highly proliferating capacity of these cells but there is accumulating evidence that this transcription factor actively plays role in tumorogenesis and tumor aggressiveness by inducing cell proliferation. Moreover, inhibition of this gene has been reported to cause a decrease in proliferation of many cancer types. Kalin et al. [17] have demonstrated that FoxM1 is continuously upregulated in metastatic prostate cancer and inhibition of FoxM1by small interfering RNA (siRNA) resulted in a decrease in proliferation of prostate cancer cells. Similarly, downregulation of FoxM1 in pancreas and breast cancer cell lines have been reported to cause a decrease in tumor growth and progression [19,26]. Regarding the role of FoxM1 in leukomogenesis, Nakamura et al. [20] investigated the cellular and molecular functions of FoxM1 in AML cells. They reported FoxM1 is highly expressed in human AML cells, and reduction of FoxM1 expression in AML cells by siRNA inhibited cell proliferation compared with normal cells. Similarly in our study, we investigated the effects of dexamethasone and siomycin A on T-ALL cells and found that dexamethasone and siomycin $A$ alone or in combination caused a significant reduction in gene expression levels of FoxM1 in a dose-dependent manner. Besides causing down-regulation of FoxM1, siomycin A has also been known to reduce the mRNA and protein levels of this transcription factor [22-24].

When we studied the effect of FoxM1 inhibition on proliferation of T-ALL cells by using siomycin A and dexamethasone, we 
Table 1

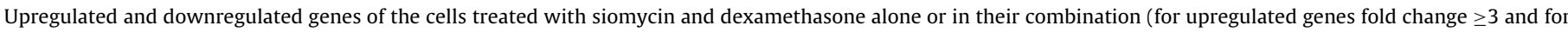
downregulated genes fold change $\leq-1.5$ ).

\begin{tabular}{|c|c|c|}
\hline & Upregulated genes (fold change) & Downregulated genes (fold change) \\
\hline \multirow[t]{5}{*}{ Siomycin A $0.46 \mu \mathrm{M}$} & $\operatorname{ADM}(4.17)$ & PPP1R15A (-1.59) \\
\hline & FASLG (3.84) & \\
\hline & FGF2 (3.73) & \\
\hline & G6PD (3.84) & \\
\hline & HMOX1 (3.07) & \\
\hline \multirow[t]{6}{*}{ Dexamethasone $10 \mu \mathrm{M}$} & CCND3 (3.36) & $\mathrm{CDH} 2(-1.97)$ \\
\hline & & DDIT3 $(-4.23)$ \\
\hline & & $\operatorname{ETS} 2(-2.41)$ \\
\hline & & KRT14 (-1.53) \\
\hline & & FOXC2 $(-1.54)$ \\
\hline & & PPP1R15A (-5.17) \\
\hline \multirow[t]{6}{*}{ Siomycin A $0.46 \mu \mathrm{M}$ and dexamethasone $10 \mu \mathrm{M}$} & CCND3 (3.41) & $\mathrm{CDC} 20(-2.60)$ \\
\hline & IGFBP7 (3.73) & $\operatorname{ETS} 2(-2.95)$ \\
\hline & G6PD (4.06) & GPD2 $(-1.61)$ \\
\hline & MAP2К3 (3.56) & $\operatorname{MCM} 2(-2.25)$ \\
\hline & SNAI3 (3.41) & $\operatorname{MK} 167(-3.56)$ \\
\hline & & KRT14 $(-1.71)$ \\
\hline
\end{tabular}

showed that $8-13 \%$ decrease in proliferation of T-ALL cells were observed when these cells were treated with 1 and $10 \mu \mathrm{M}$ doses of dexamethasone for $72 \mathrm{~h}$. On the other hand, the same doses of dexamethasone combined with siomycin A caused a much more significant decrease (unto 75\%) in proliferation of T-ALL cells. It is known that dexamethasone interacts with glucocorticoid receptors on lymphoblasts and inhibits cytokine release, causing changes in mechanisms [27]. It has been known that dexamethasone alters the expression pattern of oncogenes, inhibits cytokine release and causes arrest and apoptosis in cell cycle. There is a tendency for use of dexamethasone in remission induction period of T-cell ALL, for its better central nervous system penetrating effect and cytotoxic effects $[7,27]$. In this study, by using a specific FoxM1 inhibitor, siomycin A, a much more significant reduction has been achieved in proliferation of T-ALL cells in addition to dexamethasone. These results show that FoxM1 may play an important role in T-ALL cell proliferation and inhibition of FoxM1 may be a promising strategy for T-cell ALL treatment.

Impairments in the regulation of cell cycle have been known to play roles in development of many cancer types. It has been proposed that T-cell ALL and T-cell lymphoma are arisen by developmental arrest of precursor T lymphoblasts at certain time points during early phases of T-cell maturation [28]. Studies have shown that FoxM1 has crucial roles in cell cycle progression, cellular senescence, and stability of genomic integrity. It contributes to carcinogenesis by increasing the expression levels of some genes that are important in progression of cell cycle and by decreasing the expression levels of genes that are important in cellular senescence [29-31,13]. In our study, cell cycle analysis revealed that inhibition of FoxM1 by dexamethasone and siomycin A decreased the proliferation of T-ALL cells significantly through induction of G1 phase arrest. Recent studies have shown that FoxM1 phosphorylation starts at early G1 with cyclin-CDK complexes and continues throughout the G2 phase and mitosis [32,33].

Studies on various cancer cell lines have shown that siomycin A, by inhibiting FoxM1, inhibits cell proliferation and causes apoptosis. Bhat et al. $[23,24]$ in their studies with human melanoma, leukemia, neuroblastoma, and hepatocellular carcinoma cell lines, demonstrated that siomycin A induces apoptosis in these cancer cell lines. Similarly in our study, we examined apoptotic effects of siomycin A and observed significant increases in apoptotic cell population in the cells treated with combinations of dexamethasone and siomycin $\mathrm{A}$.

It has been suggested that the crosstalk of FoxM1 with many oncogenic pathways and other signaling pathways plays important roles in proliferation of cancer cells. FoxM1 has been shown to activate the oncogenic pathways that are important in carcinogenesis such as mitogen activated protein kinase (MAPK), extracellular signal-regulated kinase (ERK), phosphatdyl inositol 3-kinase (PI3k)/Akt), nuclear factor kappa-B and sonic hedgehog (SHH) [33-37]. Moreover, FoxM1 has been shown to decrease the gene expression levels of the tumor suppressor genes and also the genes involved in cellular senescence like $p 53$ and $p 21^{\text {cip } 1}[20,38]$. In this context, it might be expected that inhibition of FoxM1 would result in downregulation of genes involved in oncogenic pathways and cell proliferation and upregulation of genes involved in apoptosis and cellular senescence. To answer this question, we have investigated the changes in expression profiles of some genes in T-ALL cell line exposed to dexamethasone and siomycin A alone or in combination of both. We observed that expression levels of genes related with cellular senescence (MAP2K3 and IGFBP7) increased while expression levels of ETS2 protooncogene regulating telomerase activity, CDC20 gene involved in cell cycle regulation, MCM2 gene which is important in the formation of pre-replication complex and replication fork, and also MK167 gene which is involved in cell proliferation decreased in response to combinational treatment as compared to any agent.

This study is a preliminary study investigating the expression patterns of FoxM1 and also the effect of its inhibition on Jurkat cells. This study was initially planned as a cell culture study. The results were so encouraging that we have already started a prospective study with the leukemic cells obtained from patients with T-cell ALL which will allow us to better understand the expression levels and prognostic significance of FoxM1 and also its possible role for targeted therapy in T-cell ALL treatment.

In summary, our results demonstrated that FoxM1 mRNA is highly expressed in T-ALL cell lines and targeting FoxM1 by siomycin A and dexamethasone causes a significant decrease in T-ALL cell proliferation through induction of G1 cell cycle arrest. Importantly, PCR array analyses also showed that siomycin A and dexamethasone treatment affects T-ALL cell lines via upregulating or downregulating the key genes of cell cycle, apoptosis, cell proliferation, and cellular senescence. All these findings suggest a possible role for FoxM1 in T-cell ALL pathogenesis and represent FoxM1 as an attractive target for T-cell ALL therapy.

\section{Conflict of interest statement}

All authors declare that they have no conflict of interest to report. 


\section{Acknowledgements}

This research is supported by Dokuz Eylül University Scientific Research Projects Coordination Unit (Grant No: 99.3456.23). Author's contribution: ÖT was involved in the design of the study, collecting data, and writing the manuscript. MKY and YB performed the laboratory work, analyzed and interpreted data, and contributed in writing the manuscript. Gi was involved in the design of the study and interpretation of data. HÖ was involved in the design of the study, interpretation of data, writing the manuscript, and final approval of the version to be published.

\section{References}

[1] Gurney JG, Severson RK, David S, Robison LL. Incidence of cancer in children in the United States. Sex-, race-, and 1-year age-specific rates by specific histologic type. Cancer 1995;75:2186-95.

[2] Pui CH, Carroll WL, Meshinchi S, Arceci RJ. Biology, risk stratification, and therapy of pediatric acute leukemias: an update. J Clin Oncol 2011;29:551-65.

[3] Pui CH, Relling MV, Downing JR. Acute lymphoblastic leukemia. N Engl J Med 2004;8:1535-48.

[4] Bhojwani D, Howard SC, Pui CH. High-risk childhood acute lymphoblastic leukemia. Clin Lymphoma Myeloma 2009;9(Suppl. 3):222-30.

[5] Lee-Sherick AB, Linger RM, Gore L, Keating AK, Graham DK. Targeting paediatric acute lymphoblastic leukaemia: novel therapies currently in development. $\mathrm{Br}$ J Haematol 2010;151:295-311.

[6] Kraszewska MD, Davidowska M, Szczepanski T, Witt M. T-cell acute lymphoblastic leukemia: recent molecular biology findings. $\mathrm{Br} \mathrm{J}$ Haematol 2011;156:303-15.

[7] Schrappe M, Zimmermann M, Moricke A, et al. Dexamethasone in induction can eliminate one third of all relapses in childhood acute lymphoblastic leukemia (ALL): results of an international randomized trial in 3655 patients (trial AIEOPBFM ALL 2000); 2008.

[8] Laoukili J, Stahl M, Medema RH. FoxM1: at the cross roads of ageing and cancer. Biochim Biophys Acta 2007;1775:92-102.

[9] Wang Z, Ahmad A, Li Y, Banerjee S, Kong D, Sarkar FH. Forkhead box M1 transcription factor: a novel target for cancer therapy. Cancer Treat Rev 2009;36:151-6.

[10] Korver W, Roose J, Clevers H. The winged-helix transcription factor Trident is expressed in cycling cells. Nucleic Acids Res 1997;25:1715-9.

[11] Korver W, Roose J, Wilson A, Clevers H. The winged-helix transcription factor Trident is expressed in actively dividing lymphocytes. Immunobiology 1997;198:157-61.

[12] Wonsey DR, Follettie MT. Loss of the Forkhead transcription factor FoxM1 causes centrosome amplification and mitotic catastrophe. Cancer Res 2005;65:5181-9.

[13] Laoukili J, Kooistra MR, Bras A, Kauw J, Kerkhoven RM, Morrison A, et al. FoxM1 is required for execution of the mitotic programme and chromosome stability. Nat Cell Biol 2005; 7:126-36.

[14] Koo CY, Muir KW, Lam EW. FOXM1: from cancer initiation to progression and treatment. Biochim Biophys Acta 2012;1819:28-37.

[15] Kim IM, Ackerson T, Ramakrishna S, Tretiakova M, Wang IC, Kalin TV, et al. The Forkhead BoxM1 transcription factor stimulates the proliferation of tumor cells during development of lung cancer. Cancer Res 2006;66: 2153-61.

[16] Liu M, Dai B, Kang SH, Ban K, Huang FJ, Lang FF, et al. FoxM1B is overexpressed in human glioblastomas and critically regulates the tumorigenicity of glioma cells. Cancer Res 2006;66:3593-602.
[17] Kalin TV, Wang IC, Ackerson TJ, Major ML, Detrisac CJ, Kalinichenko VV, et al. Increased levels of the FoxM1 transcription factor accelerate development and progression of prostate carcinomas in both TRAMP and LADY transgenic mice. Cancer Res 2006;66:1712-20.

[18] Teh MT, Wong ST, Neill GW, Ghali LR, Philpott MP, Quinn AG. FOXM1 is a downstream target of Gli1 in basal cell carcinomas. Cancer Res 2002;62:4773-80.

[19] Wang Z, Banerjee S, Kong D, Li Y, Sarkar FH. Down-regulation of Forkhead Box M1 transcription factor leads to the inhibition of invasion and angiogenesis of pancreatic cancer cells. Cancer Res 2007;67:8293-300.

[20] Nakamura S, Hirano I, Okinaka K, Takemura T, Yokota D, Ono T, et al. The FOXM1 transcriptional factor promotes the proliferation of leukemia cells through modulation of cell cycle progression in acute myeloid leukemia. Carcinogenesis 2010;31:2012-21.

[21] Gartel AL. A new target for proteasome inhibitors: FoxM1. Expert Opin Invest Drugs 2010;19:235-42.

[22] Radhakrishnan SK, Bhat UG, Hughes DE, Wang IC, Costa RH, Gartel AL. Identification of a chemical inhibitor of the oncogenic transcription factor Forkhead box M1. Cancer Res 2006;66:9731-5.

[23] Bhat UG, Zipfel PA, Tyler DS, Gartel AL. Novel anticancer compounds induce apoptosis in melanoma cells. Cell Cycle 2008;7:1851-5.

[24] Bhat UG, Halasi M, Gartel AL. Thiazole antibiotics target FoxM1 and induce apoptosis in human cancer cells. PLoS ONE 2009;4:5592.

[25] Can G, Ekiz A, Baran Y. Imatinib induces autophagy through BECLIN-1 and ATG5 genes in chronic myeloid leukemia cells. Hematology 2011;16:95-9.

[26] Ahmad A, Wang Z, Kong D, Ali S, Li Y, Banerjee S, et al. FoxM1 downregulation leads to inhibition of proliferation, migration and invasion of breast cancer cells through the modulation of extracellular matrix degrading factors. Breast Cancer Res Treat 2010;122:337-46.

[27] Inaba H, Pui CH. Glucocorticoid use in acute lymphoblastic leukemia. Lancet Oncol 2010;11:1096-106.

[28] Bonn BR, Krieger D, Burkhardt B. Cell cycle regulatory molecular profiles of pediatric T-cell lymphoblastic leukemia and lymphoma. Leuk Lymphoma 2012;53:557-68.

[29] Wang X, Krupczak-Hollis K, Tan Y, Dennewitz MB, Adami GR, Costa RH. Increased hepatic Forkhead Box M1B (FoxM1B) levels in old-aged mice stimulated liver regeneration through diminished p27 $7^{\mathrm{Kip} 1}$ protein levels and increased Cdc25B expression. J Biol Chem 2002;277:44310-6; Katoh M. Human FOX gene family. Int J Oncol 2004;25:1495-500.

[30] Fu Z, Malureanu L, Huang J, Wang W, Li H, van Deursen JM, et al. Plk1-dependent phosphorylation of FoxM1 regulates a transcriptional programme required for mitotic progression. Nat Cell Biol 2008;10:1076-82.

[31] Wang X, Kiyokawa H, Dennewitz MB, Costa RH. The Forkhead Box M1b transcription factor is essential for hepatocyte DNA replication and mitosis during mouse liver regeneration. Proc Natl Acad Sci U S A 2002;99:16881-6.

[32] Luscher-Firzlaff JM, Lilischkis R, Luscher B. Regulation of the transcription factor FOXM1c by Cyclin E/CDK2. FEBS Lett 2006;580:1716-22.

[33] Major ML, Lepe R, Costa RH. Forkhead box M1B transcriptional activity requires binding of Cdk-cyclin complexes for phosphorylation dependent recruitment of p300/CBP coactivators. Mol Cell Biol 2004;24:2649-61.

[34] Calvisi DF, Pinna F, Ladu S, Pellegrino R, Smile MM, Frau M, et al. Forkhead box M1B is a determinant of rat susceptibility to hepatocarcinogenesis and sustains ERK activity in human HCC. Gut 2009;58:679-87.

[35] Park HJ, Carr JR, Wang Z, Nogueira V, Hay N, Tyner AL, et al. FoxM1, a critical regulator of oxidative stress during oncogenesis. EMBO J 2009;28:2908-18.

[36] Peng SL. Interplay between the NF-kappaB and Forkhead transcription factors. Cell Death Differ 2005;12:699-701.

[37] Douard R, Moutereau S, Pernet P, Chimingqi M, Allory Y, Manivet P, et al. Sonic Hedgehog-dependent proliferation in a series of patients with colorectal cancer. Surgery 2006;139:665-70.

[38] Li SK, Smith DK, Leung WY, Cheung AM, Lam EW, Dimri GP, et al. FoxM1c counteracts oxidative stress-induced senescence and stimulates Bmi-1 expression. J Biol Chem 2008;283:16545-53. 